\title{
Pengaruh Kompetensi Dan Skeptisme Profesional Terhadap Kualitas Audit
}

Auditing Quality, Competency and Skepticism

\author{
Jihan Astrid Savira, Rahmawati, Abid Ramadhan \\ Universitas Muhammadiyah Palopo \\ E-Mail: jihanastridsvv@gmail.com
}

\begin{abstract}
This study aims to determine and analyze the effect of professional competence and skepticism on audit quality. The population and sample of this study were auditors who worked at the Inspectorate Offices of Luwu Raya (Palopo City, Luwu Regency, North Luwu Regency, East Luwu Regency). The sampling technique used a census technique. The sample in this study was auditors who worked at the Inspectorate Office throughout Luwu Raya. The data collection method used a questionnaire. Kueisoner research uses a Likert scale. Data analysis using multiple linear regression analysis. This research is expected to be used as input and consideration for auditors and as a field of information for further research. The results showed that competence and skepticism had a significant positive effect on auditor quality.
\end{abstract}

Keywords: competency, skepticism, audit quality.

\begin{abstract}
ABSTRAK
Penelitian ini bertujuan untuk mengetahui dan menganalisis pengaruh kompetensi profesional dan skeptisisme terhadap kualitas audit. Populasi dan sampel penelitian ini adalah auditor yang bekerja pada Kantor Inspektorat Luwu Raya (Kota Palopo, Kabupaten Luwu, Kabupaten Luwu Utara, Kabupaten Luwu Timur). Teknik pengambilan sampel menggunakan teknik sensus. Sampel dalam penelitian ini adalah auditor yang bekerja di Kantor Inspektorat Luwu Raya. Metode pengumpulan data menggunakan kuesioner. Penelitian Kueisoner menggunakan skala likert. Analisis data menggunakan analisis regresi linier berganda. Penelitian ini diharapkan dapat menjadi masukan dan bahan pertimbangan bagi auditor dan sebagai bidang informasi untuk penelitian selanjutnya. Hasil penelitian menunjukkan bahwa kompetensi dan skeptisisme berpengaruh positif signifikan terhadap kualitas auditor.
\end{abstract}

Kata Kunci: kompetensi, skeptisisme, kualitas audit.

\section{PENDAHULUAN}

Kinerja keuangan merupakan gambaran hasil ekonomi yang mampu di raih sebuah perusahaan. Untuk meningkatkan kualitas sebuah perusahaan, salah satu hal yang harus diperhatikan adalah laporan keuangan perusahaan. Seorang auditor internal harus mampu menyajikan laporan keungan yang wajar, relevan dan dapat dipercaya karena laporan keuangan berguna untuk para pengambil keputusan serta dijadikan sebagai pedoman perbaikan menejemen dan perusahaan.

Menurut (Akbar 2014) auditor internal mempunyai peranan yang sangat penting dalam proses terciptanya akuntabilitas dan transparansi pengelolaan keuangan organisasi. Pada organisasi sektor publik, yang bertindak sebagai auditor internal salah satunya yaitu Inspektorat. Peran dan fungsi Inspektorat Provinsi, Kabupaten/Kota secara umum diatur dalam pasal 4 Peraturan Menteri Dalam Negeri No.64 Tahun 2007. Dalam pasal tersebut dinyatakan bahwa dalam melaksanakan tugas pengawasan pemerintah, Inspektorat Provinsi Kabupaten/Kota mempunyai fungsi sebagai

\section{JIAKES}

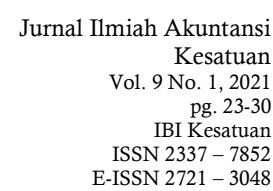
Kesatuan Vol. 9 No. 1, 2021 pg. 23-30 IBI Kesatuan
ISSN 2337-7852 E-ISSN $2721-3048$ 
Auditing Quality, Competency and Skepticism

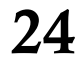

perencanaan program pengawasan, perumusan kebijakan dan fasilitas pengawasan dan pemeriksaan, pengusutan, pengujian dan penilaian tugas pengawasan.

Inspektorat sebagai auditor internal diharapkan mampu memberikan konstribusi yang penting sesuai fungsinya sebagai pemeriksa, dengan melaksanakan rencana audit dengan sikap yang professional. Selain itu juga dapat memberikan informasi berupa temuan-temuan audit yang dapat dipercaya sebagai cerminan kualitas auditnya. Audit yang berkualitas akan memberikan informasi yang memadai kepada organisasi pemerintah yang diperiksa tentang kelemahan pengendalian internal, kecurangan dan penyimpangan peraturan perundang-undangan Standar Pemeriksaan Kuangan Negara (2007) yang terjadi dalam sebuah organisasi.

Berbagai pandangan mengenai kualitas audit juga telah banyak dikemukakan oleh para ahli. Menurut De Angelo (1981) dalam (Akbar 2014) menjelaskan bahwa kualitas audit adalah kemungkinan (joint probability) seorang auditor akan menemukan dan melaporkan pelanggaran yang ada dalam sistem akuntansi kliennya. kemungkinan auditor akan menemukan salah saji akan tergantung pada pemahaman (kompetensi) auditor atas pengauditan yang pada gilirannya akan menentukan kualitas audit yang dihasilkan. Menurut (Pertiwi 2013) kualitas audit adalah pelaksanaan audit yang dilakukan sesuai dengan standar sehingga mampu mengungkapkan dan melaporkan apabila terjadi pelanggaran yang dilakukan klien. Kualitas audit menurut Standar Profesional Akuntan Publik menyatakan bahwa audit yang dilakukan auditor dikatakan berkualitas, jika memenuhi standar auditing dan standar pengendalian mutu.

Beberapa pandangan diatas dapat ditarik sebuah kesimpulan bahwa kualitas audit merupakan segala kemungkinan dimana auditor pada saat mengaudit laporan keuangan klien dan menemukan adanya pelanggaran dalam sistem akuntansi klien berhak melaporkannya dalam bentuk laporan keuangan auditan, dan berpedoman pada standar auditing. Oleh karena itu sangat penting bagi seorang auditor untuk meningkatkan kualitas audit agar tercipta sebuah kepercayaan publik terhadap keakuratan dan validitas laporan keuagan yang telah diaudit. Ketika kualitas auditor rendah maka akan memungkinkan terjadinya kecurangan saat mengaudit laporan keuangan.

Beberapa kasus skandal kecurangan manipulasi laporan keuangan rupanya masih terus menjadi sorotan masyarakat dalam beberapa tahun belakangan ini. Seperti kasus yang masih hangat terjadi (Detik.com.2019) yaitu mantan kepala Inspektorat Bojonegoro Syamsul Hadi divonis 5 tahun penjara karena telah menyalahgunakan wewenang sehingga merugikan Negara Rp. 1,7 milar. Syamsul dijadikan tersangka tunggal oleh penyidik kejari karena telah membuat kebijakan anggaran pengawasan internal. Namun kebijakan itu tidak sesuai dengan Undang-Undang. Sebagai kepala inspektorat, Syamsul Hadi dinilai tidak memberi teladan kepada masyarakat dan tidak professional dalam mengelola keuangan Negara karena menyalahgunakan kekuasaan dan wewenangnya yang diberikan untuk melanjutkan kejahatan. Kasus lainnya yang cukup hangat dan menarik dimuat oleh media online (Tirto.id.2019) yaitu kasus perusahaan multifinance PT. Sunprima Nusantara Pembiayaan (SNP Finance) diketahui merugikan 14 bank di Indonesia hingga triliunan rupiah. Dalam kasus ini Otoritas Jasa Keuangan (OJK) menjatuhkan sanksi administratif kepada dua akuntan publik (AP) dan satu kantor akuntan publik (KAP) Pangkal soalnya, AP Marlinna dan AP Merliyana Syamsul serta KAP Satrio, Bing, Eny (SBE) dan Rekan dinilai tidak memberikan opini yang sesuai dengan kondisi sebenarnya dalam laporan keuangan tahunan audit milik PT. Sunprima Nusantara Pembiayaan.

Berdasarkan fenomena-fenomena dan indikasi tersebut membuktikan bahwa kecurangan keuangan masih terus terjadi hingga saat ini. Akibatnya timbul keraguan yang mempengaruhi persepsi masyarakat, khususnya para pemakai laporan keuangan yang sangat mengharapkan laporan keuangan audit yang berkualitas. Ada beberapa faktor yang dapat mempengaruhi kualitas auditor diantaranya kompetensi dan skeptisme professional.

Beberapa bukti empiris yang menunjukkan bahwa kualitas audit dapat dipengaruhi oleh beberapa faktor, diantaranya adalah kompetensi dan skeptisme profesional. Hasil 
penelitian menurut Cahyono, dkk (2015), (Abdika, 2015) dan (Datrini, 2017) menunjukkan bahwa kompetensi berpengaruh positif terhadap kualitas audit, hasil ini cenderung disebabkan karena kompetensi merupakan hal mendasar yang harus dimiliki oleh seorang auditor, semakin tinggi pengetahuan auditor tentang audit maka akan mempermudah seorang auditor dalam melaksanakan tugasnya. sementara berbeda dengan penelitian yang dilakukan oleh Afriyani, dkk (2105) Ningsih, Sofianti (2015) dan Mutiara (2018) yang menunjukkan bahwa kompetensi tidak berpengaruh signifikan terhadap kualitas audit. Hal ini disebabkan karena kurangnya implementasi atas pengetahuan dan pengalaman yang dimiliki oleh auditor.

Hasil penelitian menurut (Abdika 2015), (Jaya et al., 2016) dan (Datrini 2017) menyimpulkan bahwa skeptisme profesional berpengaruh positif terhadap kualitas audit. Hal ini disebabkan karena dengan adanya sikap skeptis akan mampu membuat auditor lebih berhati-hati dalam menerima atau mengolah suatu informasi dari auditee, sehingga dengan hal tersebut membuat kualitas audit semakin baik. Sedangkan menurut penelitian Nandari \& Latrini (2015), Firmansyah (2018) dan Tawakkal (2019) hal ini disebabkan karena auditor kurang bersikap cermat dan seksama dalam melaksanakan tugas audit sehingga sikap skeptisme yang dimiliki oleh auditor relatif rendah.

Tujuan dalam penelitian ini yaitu untuk mengetahui apakah kompetensi dan skeptisme profesioanl berpengaruh terhadap kualitas audit pada kantor Inspektorat seLuwu Raya. Manfaat dalam penelitian ini Secara akademis, hasil penelitian ini diharapkan dapat memberikan kontribusi pemahaman mendalam tentang Pengaruh Kompetensi dan Skeptisme Profesional terhadap Kualitas Audit pada kantor Inspektorat se-Luwu Raya dan menambah wawasan ilmu pengetahuan pada bidang analisis itu sendiri. Adapun manfaat praktis Bagi penulis, menambah ilmu pengetahuan, wawasan serta pemahaman penulis mengenai Pengaruh Kompetensi dan Skeptisme Profesional terhadap Kualitas Audit dan bagi pihak perusahaan hasil penelitian ini diharapkan dapat digunakan sebagai bahan masukan dan pertimbangan mengenai Pengaruh Kompetensi dan Skeptisme Profesional.

\section{METODE PENELITIAN}

Jenis penelitian yang digunakan adalah pendekatan kuantitatif deskriptif dengan menggunakan metode survei, yaitu penelitian yang berkaitan dengan angka-angka dan dapat diukur untuk melihat pengaruh variabel independent dan terhadap variabel dependent. Populasi yang digunakan dalam penelitian ini adalah seluruh auditor yang bekerja di Kantor Inspektorat se-Luwu Raya (Kota Palopo, Kabupaten Luwu, Kabupaten Luwu Utara, Kabupaten Luwu Timur). Populasi yang digunakan dalam penelitian ini sebanyak 91 auditor di Inspektorat se-Luwu Raya. Pengambilan sampel menggunakan sampling jenuh dimana semua anggota populasi dijadikan sampel karena relatif kecil, sampel dalam penelitian ini merupakan auditor yang ditemui oleh peneliti di lokasi penelitian yaitu sebanyak 55 auditor. Tenik sampling merupakan teknik pengambilan sampel. Teknik pengambilan sampel dalam penelitian ini menggunakan metode sampling jenuh atau sensus, dimana semua anggota populasi dijadikan sampel karena pengambilan sampel relatif kecil.

Metode pengumpulan data dalam penelitian ini yaitu dengan menggunakan kuisioner yang disebarkan kepada auditor yang berada pada Kantor Inspektorat seLuwu Raya (Kota Palopo, Kabupaten Luwu, Kabupaten Luwu Utara, Kabupaten Luwu Timur). Metode ini digunakan karena wilayah penelitian masih berada dalam jangkauan peneliti. Jenis data yang digunakan dalam penelitian ini adalah data primer. Sumber data yang digunakan diperoleh melalui alat pengumpul data berupa kuisioner yang disebarkan secara langsung kepada responden. Kuisioner menggunakan Skala Likert lima poin yaitu: Setuju ( $\mathrm{SS}=5)$; Setuju $(\mathrm{S}=4)$; Netral $(\mathrm{N}=3)$; Tidak Setuju (TS = 2) dan Sangat Tidak Setuju (STS = 1).

\section{Pengembangan hipotesis}

Hubungan Kompetensi dan Kualitas Audit. Auditor diharapkan mampu mempunyai kompetensi yang memadai sesuai tugas dan tanggung jawabnya untuk
Companies'
Capital Structure
and Pecking Order

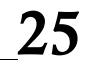


Auditing Quality, Competency and Skepticism mendapatkan hasil audit yang berkualitas. Auditor yang berkompenten adalah auditor yang dengan pengetahuan dan pengalamannya yang cukup dan eksplisit dapat melakukan audit secara objektif, cermat dan seksama (Elfarini 2007) dalam Akbar (2014). Pengetahuan dan lama pengalaman bekerja adalah faktor penting untuk meningkatkan kompetensi. Seseorang yang melakukan pekerjaan sesuai dengan pengetahuan yang dimilikinya akan memberikan hasil yang lebih baik daripada mereka yang tidak mempunyai pengetahuan yang cukup dalam menjalankan tugasnya. Begitu pula dengan pengalaman, kenyataan menunjukkan semakin menunjukkan semakin lama seseorang bekerja dan semakin banyak tugas yang dia kerjakan, akan semakin mengasah keahliannya dalam mendeteksi suatu hal yang memerlukan treatment atau perlakuan khusus yang banyak dijumpai dalam pekerjaannya. Hal ini dikarenakan dia telah benar-benar memahami teknik atau cara menyelesaikannya. Oleh karena itu dapat dipahami bahwa seseorang auditor yang memiliki kompetensi (pengetahuan dan pengalaman) yang memadai akan lebih mengetahui dan memahami kondisi keuangan dan laporan keuangan kliennya. Penelitian terdahulu yang menjelaskan tentang Kompetensi dan Kualitas Audit menunjukkan bahwa Kompetensi dan Kualitas Hasil Audit memiliki pengaruh positif dan signifikan penelitian ini dilakukan oleh Furiady \& Kurnia (2015), Cahyono, dkk (2015) dan (Abdika, 201.5).

$\mathrm{H}_{1}$ : Diduga kompetensi berpengaruh signifikan terhadap kualitas audit

Hubungan Skeptisme Profesional terhadap Kualitas Audit. Skeptisme Profesional adalah sikap (attitude) auditor dalam melakukan penugasan audit dimana sikap ini mencakup pikiran yang selalu mempertanyakan dan melakukan evaluasi secara kritis terhadap bukti audit (IAI 2011). Seseorang auditor (pemeriksa) tidak boleh menganggap bahwa manajemen organisasi yang diperiksa tidak jujur, tetapi juga tidak boleh menganggap bahwa kejujuran manajemen tersebut tidak diragukan lagi. Seorang auditor perlu menerapkan sikap skeptisme profesionalnya selama pemeriksaan, untuk mendapatkan keyakinan yang memadai bahwa salah saji material atau ketidakakuratan yang signifikan dalam data akan terdeteksi, baik karena kesalahan, kecurangan, tindakan melanggar hukum atau pelanggaran peraturan. Penerapan skeptisme professional oleh auditor secara memadai dalam setiap pemeriksaan membawa dampak tercapainya hasil audit yang berkualitas. Penelitian terdahulu yang menjelaskan tentang Skeptisme Profesional dan Kualitas Audit menunjukkan bahwa Skeptisme Profesional dan Kualitas Hasil Audit memiliki pengaruh positif dan signifikan penelitian ini dilakukan oleh dan Jaya, et al. (2016).

$\mathrm{H}_{2}$ : Diduga skeptisme profesional berpengaruh signifikan terhadap kualitas audit.

\section{HASIL DAN PEMBAHASAN \\ Hasil Uji Validitas Data}

Pengujian validitas dala dalam penelitian ini dilakukan dengan cara statistik yaitu menghitung kolerasi antara masing-masing pertanyaan dengan skor total dengan menggunakan metode product moment personcorrelation. Data dinyatakan valid jika nilai $\mathrm{r}_{\text {hitung }}$ yang merupakan nilai item dari correctedi Item - Total Correlation $>$ dari $\mathrm{r}_{\text {tabel }}$ pada signifikan $0,05(5 \%)$. Berikut ini disajikan validitas dari masing-masing varibel pada tabel 1. Berdasarkan tabel tersebut, dapat diketahui semua item pernyataan untuk semua variabel adalah valid. Karena nilai Corected Item-Correlation $>\mathrm{r}$ tabel pada signifikan $0,05(5 \%)$.

\section{Hasil Uji Reliabilitas Data}

Reliabilitas adalah alat ukur untuk mengukur suatu kuesioner yang merupakan indikator dari variabel. Suatu kuesioner dikatakan reliable jika jawaban dari responden itu stabil dari waktu ke waktu. Nilai ketentuan untuk mengukur realibilitas dengan uji statistik Cronbach Alpha ( $\alpha$ ). Suatu konstruk dinyatakan reliabel jika memiliki Conbach Alpha> 0,60. Berdasarkan tabel 2 dapat disimpulkan bahwa seluruh variabe yang digunakan pada penelitian ini telah reliabel karena secara keseluruhan variabel memiliki 
nilai Cronbach Alpha yang lebih besar dari 0,60 sehingga layak digunakan untuk menjadi alat ukur instrumen kuesioner dalam penelitian ini.

Tabel 1. Hasil Uji Validitas

\begin{tabular}{|c|c|c|c|c|}
\hline Variabel & Item & r hitung & r tabel & Keterangan \\
\hline \multirow{6}{*}{ Kompetensi } & $\mathrm{X}_{1.1}$ & 0,774 & 0,2656 & Valid \\
\hline & $\mathrm{X}_{1.2}$ & 0,801 & 0,2656 & Valid \\
\hline & $\mathrm{X}_{1.3}$ & 0,687 & 0,2656 & Valid \\
\hline & $\mathrm{X}_{1} .4$ & 0,585 & 0,2656 & Valid \\
\hline & $\mathrm{X}_{1.5}$ & 0,703 & 0,2656 & Valid \\
\hline & $X_{1} .6$ & 0,770 & 0,2656 & Valid \\
\hline \multirow{6}{*}{$\begin{array}{c}\text { Skeptisme } \\
\text { Profesionalisme }\end{array}$} & $\overline{X_{2.1}}$ & 0,693 & 0,2656 & Valid \\
\hline & $\mathrm{X}_{2.2}$ & 0,776 & 0,2656 & Valid \\
\hline & $X_{2.3}$ & 0,756 & 0,2656 & Valid \\
\hline & $\mathrm{X}_{2.4}$ & 0,718 & 0,2656 & Valid \\
\hline & $X_{2.5}$ & 0,796 & 0,2656 & Valid \\
\hline & $\mathrm{X}_{2.6}$ & 0,664 & 0,2656 & Valid \\
\hline \multirow{6}{*}{ Kualitas Audit } & $\mathrm{Y}_{1}$ & 0,835 & 0,2656 & Valid \\
\hline & $\mathrm{Y}_{2}$ & 0,799 & 0,2656 & Valid \\
\hline & $\mathrm{Y}_{3}$ & 0,612 & 0,2656 & Valid \\
\hline & $\mathrm{Y}_{4}$ & 0,811 & 0,2656 & Valid \\
\hline & $\mathrm{Y}_{5}$ & 0,597 & 0,2656 & Valid \\
\hline & $\mathrm{Y}_{6}$ & 0,834 & 0,2656 & Valid \\
\hline
\end{tabular}

Tabel 2. Hasil Uji Reliabilitas

\begin{tabular}{|l|c|c|c|}
\hline \multicolumn{1}{|c|}{ Variabel } & Alpha Cronbach's & $\begin{array}{c}\text { Batas } \\
\text { Reliabilitas }\end{array}$ & Keterangan \\
\hline Kompetensi (X1) & 0,809 & 0,60 & Reliabel \\
\hline Skeptisme Profesional (X2) & 0,838 & 0,60 & Reliabel \\
\hline Kualitas Audit (Y) & 0,822 & 0,60 & Reliabel \\
\hline
\end{tabular}

Sumber: Data Primer Diolah

\section{Analisis Regresi Berganda}

Analisis regresi linear berganda digunakan untuk mengetahui ada atau tidaknya pengaruh dua atau lebih variabel independen $(\mathrm{X})$ terhadap variabel dependen $(\mathrm{Y})$. Pengaruh variabel independen diantaranya kompetensi dan skeptisme profesional terhadap variabel dependen yaitu kualitas audit. Hasil dari model regresi dilihat sebagai berikut:

Tabel 3. Rangkuman Hasil Analisis Regresi Berganda

\begin{tabular}{lccccc}
\hline \multicolumn{1}{c}{ Variabel } & \multicolumn{2}{c}{ Unstandardized } & Standardized & Coefficients & Coefficients \\
& $\mathrm{B}$ & Std. Error & Beta & t & Sig. \\
& 8,643 & 4,017 & & 2,151 &, 038 \\
(Constant) & 1,026 &, 242 &, 473 & 4,239 &, 000 \\
Kompetensi &, 580 &, 186 &, 348 & 3,117 &, 003 \\
\hline Skeptisme Profesional &
\end{tabular}

Sumber: Hasil Pengolahan Data SPSS 2020

Dari hasil perhitungan regresi liniear berganda diatas, dapat dilihat bahwa hubungan antara variabel independen dan variabel dependen diungkapkan oleh rumus berikut:

$\mathrm{Y}=19,751+1,026 \mathrm{X}_{1}+0,580 \mathrm{X}_{2}+\mathrm{e}$

Dimana:

$\begin{array}{lll}Y & : \text { Kualitas Audit } & x_{1}: \text { Kompetensi } \\ \mathrm{b} & : \text { Konstanta } & x_{2}: \text { Skeptisme Profesional } \\ e & : \text { Standar eror } & \end{array}$


Auditing Quality, Competency and Skepticism

\section{Hasil Uji Parsial (Uji t)}

Uji t digunakan untuk menguji hipotesis secara parsial seberapa besar pengaruh antara satu variabel independen dengan variabel dependennya. Jika nilai probabilitas signifikan $<0,05$, maka berarti suatu variabel independen merupakan penjelas yang signifikan terhadap variabel dependennya. Variabel independen meliputi Kompetensi dan Skeptisme Profesional, variabel dependennya yaitu Kualitas Audit. Berdasarkan hasil yang ditampilan pada tabel 3 diatas, pengujian hipotesis dengan menggunakan uji $t$ diperoleh hasil sebagai berikut:

a. Uji $t$ antara Kompetensi dengan Kualitas audit menunjukkan hasil $t_{\text {hitung }} 4,239>t_{\text {tabel }}$ 1,647 dengan nilai signifikan sebesar $0,000<0,05$ maka diperoleh bahwa Kompetensi Secara parsial memiliki pengaruh positif terhadap Kualitas Audit.

b. Uji $\mathrm{t}$ antara Skeptisme Profesional dengan Kualitas Audit menunjukkan hasil $\mathrm{t}$ hitung $3,117>t_{\text {tabel }} 1,674$ dengan nilai signifikan sebesar $0,003<0,05$, maka diperoleh bahwa Skeptisme Profesional secara parsial memiliki pengaruh positif terhadap Kualitas Audit.

\section{Hasil Uji Koefisien Determinasi $\left(\mathbf{R}^{2}\right)$}

Uji koefisien determinasi dalam regresi linear berganda digunakan untuk mengetahui seberapa besar kontribusi pengaruh variabel independen terhadap variabel dependennya. Berikut hasil olah data untuk koefisien determinasi.

Tabel 5. Hasil Uji Koefisien Determinasi $\left(R^{2) .}\right.$

\begin{tabular}{lrrrr}
\hline Model & R & R Square & Adjusted R Square & Std. Error of the Estimate \\
\hline 1 & $.711^{\text {a }}$ & .506 & .487 & 3.31276 \\
\hline
\end{tabular}

Sumber: Hasil pengolahan SPSS 2020

Berdasarkan tabel tersebut menunjukkan $\mathrm{R}^{2}$ diperoleh nilai $\mathrm{R}^{2}$ sebesar 0,487 atau 48,7\%. Nilai tersebut menunjukkan seberapa besar hubungan antara variabel bebas dengan variabel terikatnya. Pada penelitian ini terdapat hubungan yang kuat antara variabel Kompetensi dan Skeptisme Profesional terhadap Kualitas Audit. Untuk sisanya sebesar 51,3\% dijelaskan pada faktor-faktor diluar model analisis.

\section{Pembahasan \\ Pengaruh Kompetensi terhadap Kualitas Audit}

Hasil penelitian pengaruh kompetensi terhadap kualitas hasil audit medukung hipotesis pertama yang menyatakan "kompetensi berpengaruh terhadap kualitas audit". Berdasarkan hasil uji hipotesis dimana kompetensi audit menunjukkan hasil $t_{\text {hitung }}$ 4,239> $t_{\text {tabel }} 1,647$ dengan nilai signifikan sebesar $0,000<0,05$ maka diperoleh Kompetensi Secara parsial memiliki pengaruh positif terhadap Kualitas Audit. Kondisi ini menggambarkan bahwa semakin kuat dan tinggi Kompetensi auditor maka akan semakin meningkatkan kualitas audit sehingga hal ini akan berpengaruh baik terhadap hasil pemeriksaan auditor. Penelitian ini berhubungan dengan teori atribusi yang menjelaskan bahwa perilaku seseorang itu bersifat rasional. Perilaku seseorang berhubungan dengan sikap dan karakteristik individu sehingga sikap dan kerakteristik mampu menghadapi situasi di segala lingkungan. Teori atribusi dipengaruhi oleh dua faktor, yaitu internal dan eksternal. Dalam penelitian ini variabel kompetensi merupakan faktor internal yang mempengaruhi kualitas audit dimana seorang auditor harus memiliki kompetensi yang memadai sehingga membantu dalam menghadapi kegiatan pemeriksaan terhadap laporan keuangan. Disamping itu, seorang auditor harus memiliki pengalaman dan pengethuan agar lebih terampil dalam mengerjakan proses audit dan menghasilkan hasil audit yang berkualitas. Hasil penelitian ini juga sejalan dengan penelitian yang dilakukan oleh (Furiady \& Kurnia, 2015), Abdika (2015) dan penelitian Datrini (2017) yang menyatakan bahwa kompetensi berpengaruh secara signifikan terhadap kualitas hasil audit.

\section{Pengaruh Skeptisme Professional terhadap Kualitas audit}

Hasil penelitian pengaruh skeptisme profesional terhadap kualitas hasil audit medukung hipotesis pertama yang menyatakan "skeptisme profesional berpengaruh 
terhadap kualitas audit". Berdasarkan hasil uji hipotesis dimana skeptisme Audit menunjukkan hasil $\mathrm{t}_{\text {hitung }} 3,117>\mathrm{t}_{\text {tabel }} 1,674$ dengan nilai signifikan sebesar $0,003<0,05$, maka diperoleh bahwa Skeptisme Profesional secara parsial memiliki pengaruh positif terhadap Kualitas Audit. Kondisi ini menggambarkan bahwa semakin kuat dan tinggi Skeptisme Profesional seorang auditor maka akan semakin meningkatkan kualitas audit sehingga hal ini akan berpengaruh baik terhadap hasil pemeriksaan auditor. Penelitian ini sejalan dengan teori atribusi dimana perilaku seseorang dipengaruhi oleh dua faktor yaitu internal dan eksternal. Variabel skeptisme professional merupakan faktor internal yang dapat mempengaruhi kualitas audit, dimana auditor yang skeptis memiliki sikap yang selalu mempertanyakan setiap kejadian yang dihadapinya, sehingga muncul rasa ragu dan ingin mencari tahu lebih dalam mengenai sesuatu yang dikerjakannya. Dengan demikian, skeptisme professional sangat penting untuk dimiliki oleh seorang auditor untuk menjalankan proses pengauditan yang dapat mendeteksi dan mencegah kemungkinan kecurangan yang akan terjadi, dengan kemampuan skeptisme yang tinggi tentu saja akan menghasilkan proses audit yang baik. Penelitian ini sejalan dengan penelitian yang dilakukan oleh (Abdika 2015), (Jaya et al., 2016) dan (Datrini 2017) yang menyatakan bahwa skeptise profesional berpengaruh positif dan signifikan terhadap kualitas audit.

\section{PENUTUP}

Berdasarkan hasil analisis, pengujian hipotesis dan pembahasan yang telah dilakukan yaitu mengenai kompetensi dan skeptisme profesional terhadap kualitas audit pada Kantor Inspektorat se-Luwu Raya (Kota Palopo, Kabupaten Luwu, Kabupaten Luwu Utara dan Kabupaten Luwu Timur) maka dapat disimpulkan bahwa Kompetensi dan Skeptisme berpengaruh signifikan terhadap kualitas audit pada Kantor Inspektorat se-Luwu Raya (Kota Palopo, Kabupaten Luwu, Kabupaten Luwu Utara dan Kabupaten Luwu Timur).

\section{DAFTAR PUSTAKA}

Abdika, C. L. (2015). Terhadap Kualitas Audit Auditor Badan Pemeriksa Keuangan (Bpk) Republik Indonesiadan Badan Pengawas Keuangan Dan Pembangunan ( Bpkp) Perwakilan Provinsi. 2(2), 1-15.

Firmansyah, A. (2018). Pengaruh kompetensi, independensi, skeptisisme Profesional, akuntabilitas, fee audit dan Objektivitas terhadap kualitas audit (Doctoral dissertation, Stie Perbanas Surabaya).

Budiman, H., Yusnaini, Y., \& Relasari, R. (2019). Pengaruh Due Professional Care Dan Akuntabilitas Terhadap Kualitas Audit. Akuntabilitas: Jurnal Penelitian dan Pengembangan Akuntansi, 11(2), 139-150.

Cahyono, A. D., Wijaya, A. F., \& Domai, T. (2015). Pengaruh Kompetensi, Independensi , Obyektivitas, Kompleksitas Tugas, Dan Integritas Auditor Terhadap Kualitas Hasil Audit. ISSN: 2088-7469. Malang : Jurnal Reformasi, Vol. 5(No. 1), 1-12.

Datrini, N. L. A. S. L. K. (2017). Pengaruh Skeptisme Profesional , Independensi, Kompetensi, Etika, Dan Role Stress Auditor Terhadap Kualitas Audit Pada Kantor BPK RI Perwakilan Provinsi Bali. Jurnal Krisna (Kumpulan Riset Akuntansi), 9(2301-8879), 1-14.

Furiady, O., \& Kurnia, R. (2015). The Effect of Work Experiences, Competency, Motivation, Accountability and Objectivity towards Audit Quality. Procedia Social and Behavioral Sciences, 211, 328-335.

Furiady, Olivia \& Kurnia, Ratnawati (2015) The Effect of Work Experiences, Competency, Motivation, Accountability, and Objectivity towards Audit Quality. Global Conference on Business and Social Science-2015, GCBSS-2015, 17-18 September 2015, Bali, Indonesia.

Https://m.detik.com.(2019).
Capital Structure and Pecking Order 
Auditing Quality, Competency and Skepticism https://tirto.id. (2019)

Ikatan Akuntan Indonesia. 2001. Standar Profesional Akuntan Publik. Salemba 4, Jakarta.

Jaya, T. E., Irene, \& Choirul. (2016). Skepticism, Time Limitation of Audit, Ethics of Professional Accountant and Audit quality (Case Study in Jakarta, Indonesia). Review of Integrative Business and Economics Research, 5(3), 173-182.

Knoers dan Haditono. 1999. "Psikologi Perkembangan: Pengantar Dalam Berbagai Bagiannya". Cetakan Ke-12. Yogyakarta: Gajah Mada University Press.

Kusharyanti 2003. "Temuan Penelitian Mengenai Kualitas Audit dan Kemungkinan Topik Penelitian di Masa Datang". Jurnal Akuntansi dan Manajemen.

Mutiara, I. (2018). Pengaruh Kompetensi Dan Independensi Auditor Terhadap Kualitas Audit Dengan Etika Auditor Sebagai Variabel Moderasi. Jurnal Riset Akuntansi Jambi, 1(2), 33-39.

Mulyadi. 2002. Auditing. PT. Salemba Empat. Jakarta

Nandari, A., \& Latrini, M. (2015). Pengaruh Sikap Skeptis, Independensi, Penerapan Kode Etik, Dan Akuntabilitas Terhadap Kualitas Audit. E-Jurnal Akuntansi, 10(1), 164-181.

Pengaruh Skeptisisme Profesional Auditor, Kompetensi, Independensi Dan Kompleksitas Audit Terhadap Kualitas Audit. (2008). Jurnal Ekonomi, Manajemen, Akuntansi I, 21(2), 181-198.

Pertiwi, R. A. (2013). Pengaruh Kompetensi, Independensi Dan Profesionalisme Terhadap Kualitas Audit (Studi Empiris Pada Kantor Akuntan Publik Se Sumatera). Jurnal Ekonomi, 21(3), 2-3.

Robbins, Stephen and Judge, T. (2014). Perilaku Organisasi (12th ed.). Jakarta: Salemba Empat.

Sekaran, (2006). Metodologi Penelitian Untuk Bisnis. Edisi Keempat. Jakarta: Salemba Empat.

Scully, S.G. 1993. The Effect of Audit Team Structure and Task Complexity on Auditor Confidence. Western Australia.

Sugiyono. 2012. Metode Penelitian Kuantitatif Kualitatif dan R\&D. Bandung: Alfabeta. Sunyoto, D. 2016. Metodologi Penelitian Akuntansi. Bandung: PT. Refika Aditama

Tjun, L. T., Marpaung, E. I., \& Setiawan, S. 2012. Pengaruh Kompetensi dan Independensi Auditor terhadap Kualitas Audit. Jurnal Akuntansi, 4 (1).

Tresno Eka Jaya, Irene \& Choirul.(2016). Skepticism, Time Limitation of Audit, Ethics of Profesional Accountant and Audit Quality Case Study in Jakarta, Indonesia. Review of Integrative Business and Economics Research. Vol 5(3). 173-182 